\title{
Adaptation of digestive enzymes to dietary protein, carbohydrate and fibre levels and influence of protein and carbohydrate quality in Penaeus vannamei larvae (Crustacea, Decapoda)
}

\author{
Gilles Le Moullac ${ }^{(1,2)}$, Alain Van Wormhoudt ${ }^{(1)}$ and AQUACOP \\ (1) Laboraloire de Biologie marine, Collège de France, place de La Croix, B.P. 225, 29182 Concameau, France. \\ (2) IFREMER, Centre Océanologique du Pacifique, B.P. 7004, Vairao, French Polynesia.
}

Received December 20, 1993; accepted February 21, 1994.

Le Moullac G., A. Van Wormhoudt, AQUACOP. Aquat. Living Resour., 1994, 7, 203-210.

\begin{abstract}
Activity of digestive enzymes (trypsin, chymotrypsin and amylase) was studied in relation with food in Penaeus vannamei larvae first stages. Microparticles containing casein involved the decrease of soluble protein content and enzyme activities. Specific trypsin activity but not chymotrypsin was correlated $(p<1 \%)$ to casein level between 10 and $60 \%$ in microparticles. Cellulose fibres in food seemed to have little effect on digestive enzymes. Starch, between 1 and $20 \%$ in microparticles, had no influence on specific amylase activity. The effect of different feeding conditions were also tested on growth. No clear relationship between growth and enzyme is established since only trypsin is concerned in the case of a casein dose effect in the food. The protein source (casein, gelatin, squid meal or fish protein soluble concentrate) as well as the carbohydrate quality (soluble starch, standard corn starch, amylopectin corn starch or pregelatinized corn starch) were tested. Squid meal stimulated significantly chymotrypsin activity $(p<2 \%)$ while trypsin activity decreased with fish protein soluble concentrate $(p<5 \%)$. Source of carbohydrate seemed very important, amylase activity increased significantly $(p<2 \%)$ with corn starch. These adaptations are not correlated to growth performances since squid meal or fish protein soluble concentrate improved larval development until zoe 3 substage. These results suggest a specific induction of digestive enzymes to the food quality in larvae independent of growth performances.
\end{abstract}

Keywords: Penaeus vannamei, larvae, food, digestive enzymes, trypsin, chymotrypsin, amylase.

Adaptation des enzymes digestives à la teneur en protéines, en glucides et en fibres: influence de la qualité des protéines et des glucides dans l'aliment chez les larves de Penaeus vannamei (Crustacea, Decapoda).

Résumé

L'activité des enzymes digestives (trypsine, chymotrypsine et amylase) au cours des premiers stades larvaires de Penaeus vannamei est étudiée en relation avec l'alimentation. Les microparticules à base de caséine diminuent le contenu protéique soluble et les activités enzymatiques. L'activité spécifique de la trypsine est corrélée $(p<1 \%)$ au taux de caséine entre 10 et $60 \%$ dans les microparticules, mais pas la chymotrypsine. L'amidon, entre 1 et $20 \%$ dans l'aliment, n'a aucun effet sur l'activité spécifique de l'amylase. De même, les fibres de cellulose semblent avoir peu d'effet sur l'activité des enzymes digestives. Les effets de différentes conditions d'alimentation sont aussi testés sur la croissance. La relation entre la croissance et les enzymes n'est pas clairement établie alors que seule la trypsine est concernée par un effet dose de caséine dans l'aliment. L'origine des protéines (caséine, gélatine, farine de calmar et concentré protéique soluble de poisson) ainsi que la qualité de l'amidon (amidon soluble, amidon de maiss standard, amidon de maïs riche en amylopectine et amidon de maïs prégelatinisé) sont testées. La farine de calmar stimule significativement $(p<2 \%)$ l'activité de la chymotrypsine alors que l'activité de la trypsine est significativement plus faible $(p<5 \%)$ avec le concentré protéique soluble de poisson. La source de glucide semble importante, l'activité de l'amylase augmente significativement $(p<2 \%)$ avec l'amidon de maïs. Ces adaptations ne sont pas corrélées aux performances de croissance alors que la farine de calmar et le 
concentré protéique soluble de poisson accélèrent le développement larvaire, le gain à zoé 3 est de 1 jour. Ces résultats suggèrent une induction spécifique des enzymes digestives liée à la qualité de l'aliment chez les larves, indépendamment des performances de croissance.

Mots-clés : Penaeus vannamei, larve, alimentation, enzymes digestives, trypsine, chymotrypsine, amylase.

\section{INTRODUCTION}

Larval feeding is traditionally composed of a mixture of algae and Artemia nauplii given empirically (Mock and Murphy, 1969). Research findings on larval shrimp nutrition have advanced sufficiently to permit development of microparticles as substitutes for live food (Jones et al., 1979; Teshima and Kanazawa, 1983) and similar growth has been measured at zoe substages, in groups receiving live and microparticulate seeds (AQUACOP et al, 1990). The relationship between larval growth and protein or carbohydrate level in diet has been studied by Teshima and Kanazawa (1984) who have determined the optimum of proteins around $50 \%$ and of carbohydrates between 15 and 20\%. Growth becomes more efficient when larvae are fed diets containing fish meals and squid meal (Cuzon and Guillaume, 1986; Koshio et al., 1992).

The ontogenetic changes in digestive enzymes have been used to adjust diets to the crustacean digestive activity (Laubier-Bonnichon et al., 1977; Hirch and Anger, 1987; Lovett and Felder, 1990; Fang and Lee, 1992). The relationship between food substrate and digestion in crustaceans has been also investigated in small crustaceans but mainly in adults, and contradictory results were obtained according to the species, the size of animals and the nature of food constituents. A repressive regulatory mechanism for enzymes under saturating food conditions has been shown for Artemia salina (Samain et al., 1985) and the copepod Calanus helgolandicus (Harris et al., 1986), whereas has been shown to for Calanus hyperboreus, no specific induction of digestive enzymes occur (Head and Conover, 1983). In larger crustaceans such as Penaeus japonicus, starvation involves a decrease in specific activity of amylase but not of trypsin (Cuzon $e t$ al., 1980). However, adaptation of digestive enzymes level to the composition of experimental diets in Palaemon serratus (Van Wormhoudt et al., 1980) and in Homarus gammarus (Lucien-Brun et al., 1985) has been measured. For Penaeus vannamei, Lee et al. (1984) have shown an adaptation of digestive enzymes according to the shrimp size, the protein sources and the protein level in the diet, whereas in Penaeus setiferus, enzyme activities varied inversely to the protein level in diet (Lee and Lawrence, 1985).

This study, reports, for the first time, the limits of adaptation of digestive enzymes of Penaeus vannamei larvae, mainly at zoe substages, to different protein,
Table 1. - Microparticle formulas (for $100 \mathrm{~g}$ ) according to Teshima and Kanazawa (1984).

\begin{tabular}{|c|c|c|c|c|c|c|}
\hline \multirow{2}{*}{$\begin{array}{l}\text { Ingredients } \\
\text { Casein }^{\mathbf{a}}\end{array}$} & \multicolumn{3}{|c|}{$\begin{array}{c}\text { Protein and cellulose } \\
\text { levels }(\%)\end{array}$} & \multicolumn{3}{|c|}{$\begin{array}{l}\text { Carbohydrate and } \\
\text { cellulose levels }(\%)\end{array}$} \\
\hline & 10 & 50 & 60 & 50 & 50 & 50 \\
\hline Cod liver oil & 4 & 4 & 4 & 4 & 4 & 4 \\
\hline Lecithin & 2 & 2 & 2 & 2 & 2 & 2 \\
\hline Cholesterol & 0.5 & 0.5 & 0.5 & 0.5 & 0.5 & 0.5 \\
\hline Starch ${ }^{b}$ & 10 & 10 & 10 & 1 & 10 & 20 \\
\hline Glucose & 3 & 3 & 3 & 3 & 3 & 3 \\
\hline Saccharose & 3 & 3 & 3 & 3 & 3 & 3 \\
\hline Glucosamine & 0.8 & 0.8 & 0.8 & 0.8 & 0.8 & 0.8 \\
\hline Minerals $\mathbf{c}$ & 8 & 8 & 8 & 8 & 8 & 8 \\
\hline Vitamins ${ }^{d}$ & 5 & 5 & 5 & 5 & 5 & 5 \\
\hline Arginine & 0.5 & 0.5 & 0.5 & 0.5 & 0.5 & 0.5 \\
\hline Methionine & 0.5 & 0.5 & 0.5 & 0.5 & 0.5 & 0.5 \\
\hline Alanine & 0.5 & 0.5 & 0.5 & 0.5 & 0.5 & 0.5 \\
\hline Cellulose & 52.2 & 12.2 & 2.2 & 21.2 & 12.2 & 2.2 \\
\hline$\kappa$-Carragheenan & 5 & 5 & 5 & 5 & 5 & 5 \\
\hline
\end{tabular}

Vitamin-free Casein, Merck.

b Soluble starch, Sigma.

cd Kanazawa et al., 1977.

carbohydrate and cellulose levels and different protein sources and starch qualities in microparticulate diets. The absence of apparent effect of cellulose in food was reported.

\section{MATERIAL AND METHODS}

Larvae were obtained from captive breeders and reared according to the standard established by AQUACOP (1982) for control larvae fed unicellular algae and Artemia salina nauplii, and by AQUACOP et al. (1990) for the microparticle fed experimental larvae. Larvae were reared in filtered seawater ( 37 ppt salinity, $27^{\circ} \mathrm{C}$ ) in 200 liters cylindroconical tanks under artificial light. Initial density was 180 nauplii/liter.

Control larvae were fed with a cocktail of unicellular algae composed of Isochrysis galbana given at zoe 1 (Z1) substage $(15000$ cells/ml), Chaetoceros calcitrans at zoe 2 (Z2) and zoe 3 (Z3) substages (50000 cells $/ \mathrm{ml})$ and Artemia salina nauplii at mysis substages, 10/mysis 1 (M1), 25/mysis 2 (M2) and 35/mysis 3 (M3) per day. Microparticles containing $50 \%$ casein and $10 \%$ starch were made according to Teshima et al. (1983). They were given every four hours with the help of automatic feeders from Z1 
Table 2. - Proximal analysis of shrimp larval live food: unicellular algae and Artemia salina nauplius (\% dry basis).

\begin{tabular}{lccc}
\hline Constituent & $\begin{array}{c}\text { Isochrysis } \\
\text { galbana }\end{array}$ & $\begin{array}{c}\text { Chaetoceros } \\
\text { calcitrans }\end{array}$ & Artemia salina \\
\hline Crude protein & 37 & 25 & 55 \\
Crude fat & 12 & 10 & 20 \\
Ash & 23 & 37 & 10 \\
\hline
\end{tabular}

a Rubio Rincon, 1993.

b Aujero et al., 1983.

c Sun Pan et al., 1991.

to $\mathrm{Z3}$ in the experimental batches, $6 \times 0.64 \mathrm{~g} /$ day at $\mathrm{Z} 1,6 \times 1.00 \mathrm{~g} /$ day at $\mathrm{Z} 2$ and $6 \times 1.20 \mathrm{~g} /$ day at $\mathrm{Z3}$. Microparticle size was less than $125 \mu \mathrm{m}$. Composition of the microparticles is given in table 1 , and algae and Artemia salina nauplius proximate analysis is given in table 2.

\section{Effect of live food and artificial diet}

The effects of feeding algae or microparticles at zoe stage and Artemia nauplii at mysis stage were compared. In this experiment, animals were taken at each new substage in each treatment from a single observation. Experiment was stopped at M3.

\section{Effect of protein and carbohydrate levels}

At zoe stage, the effect of three levels of casein as protein source in microparticles $(10,50$ and $60 \%$ of casein) and three levels of soluble starch as the carbohydrate source in microparticles $(1,10$ and $20 \%$ ) were determined (table 1). Formulas were ballasted with cellulose. Treatments were conducted in duplicate. Experiments were stopped at day 8.

\section{Protein and carbohydrate quality}

The effects of casein (CAS), gelatin (GEL), squid meal (CAL) and soluble fish protein concentrate (CPSP) as protein sources at constant protein level $(50 \%)$ in microparticulate diets in zoe larvae were determined. GEL, CAL and CPSP were incorporated in formula in relation to their proximal composition (table 3). Lipid and carbohydrate were respectively incorporated to 6 and 10\%. Effect of starch quality were determined on zoe larvae. Four starches, incorporated into the control formula at $10 \%$, were

Table 3. - Proximal analysis of gelatin, squid meal and protein fish soluble concentrate (\%) incorporated in microparticles.

\begin{tabular}{lcccc}
\hline Protein sources & Protein & Lipid & Ash & Moisture \\
\hline Gelatin & 88 & 0 & 2 & 10 \\
Squid meal & 71 & 6 & 10 & 9 \\
Fish protein soluble $^{\text {concentrate }}$ & 85 & 5 & 6 & 4 \\
\hline
\end{tabular}

a Solatlante CPSP90, SANOFI. compared: soluble starch A1, standard corn starch A2, corn starch with a high amylopectin content A3 and pregelatinized corn starch A4. Soluble starch was supplied by Sigma Chemicals Corporation, corn starches (A2, A3 and A4) were provided by Roquette. Formulas were ballasted with cellulose. Each treatment were conducted in duplicate. Experiments were stopped at day 8.

\section{Enzyme analysis}

Larvae (around 100) were caught on plankton mesh, frozen and freeze-dried. The freeze-dried larvae were homogenized in phosphate buffer $10 \mathrm{mM}$ pH 7 using a tissue grinder. Homogenates were centrifuged at $13000 \mathrm{rpm}$ for $10 \mathrm{~min}$ at $4^{\circ} \mathrm{C}$ and the supernatant was collected and stored at $-70^{\circ} \mathrm{C}$. Soluble protein content was measured by the Lowry method (1964) using bovine serum albumin (BSA) as standard. Trypsic activity was estimated using N-Benzoyl-L-Arginine$\mathrm{p}$-Nitroanilide (BAPNA) as substrate in Tris buffer
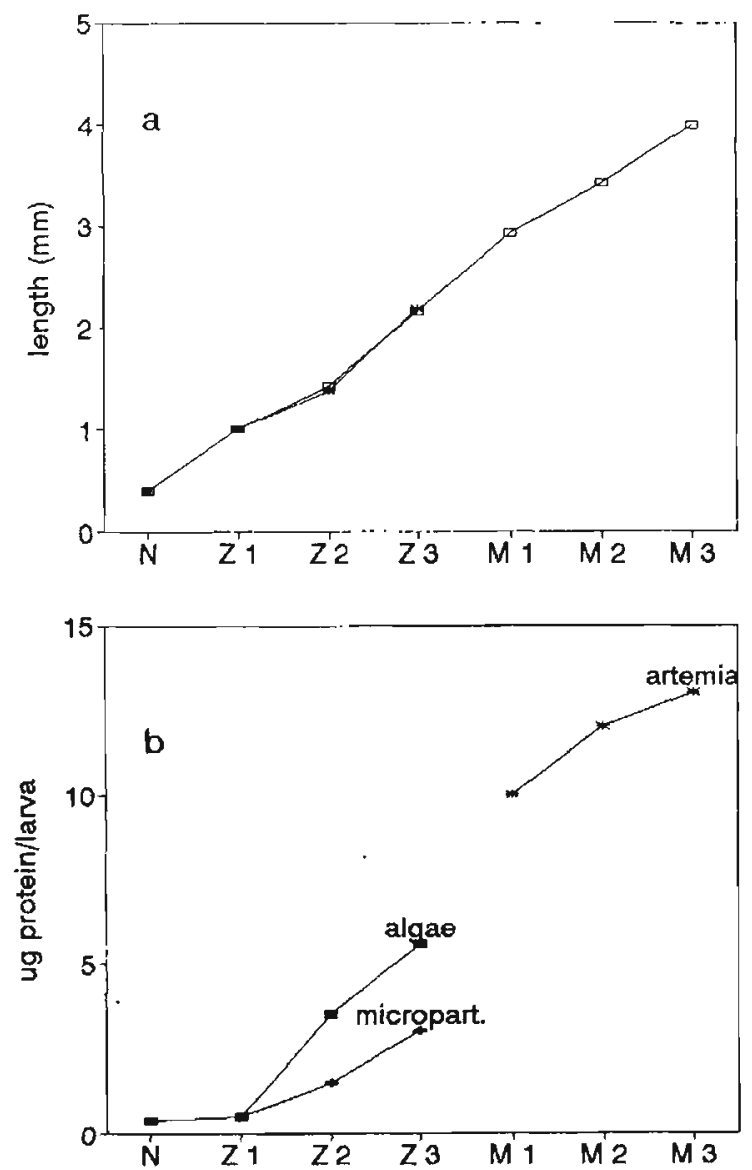

Figure 1. - Penaeus vannamei larval growth, comparison between zoe substages fed with algae and microparticles, mysis substages were fed with Artemia nauplii. (a) Larval length, each point represents the average of 10 observations. Larval length is the distance between telson and rostrum base. (b) Individual soluble protein content of $P$. vannamei larvae. Each point represents the mean of two observations. 
$0.1 \mathrm{M} \mathrm{pH} 8$ (Erlanger et al., 1961). Chymotrypsin activity was assayed with Succinyl-(Ala) $)_{2}$-ProlinePhenylalaline-p-Nitroanilide (SAPPNA) as substrate in Tris buffer $0.1 \mathrm{M} \mathrm{pH} 8$ (Delmer et al., 1979). Amylase activity was estimated after glycogen hydrolysis at $37^{\circ} \mathrm{C}$ with the Bernfeld method (1955). One unit
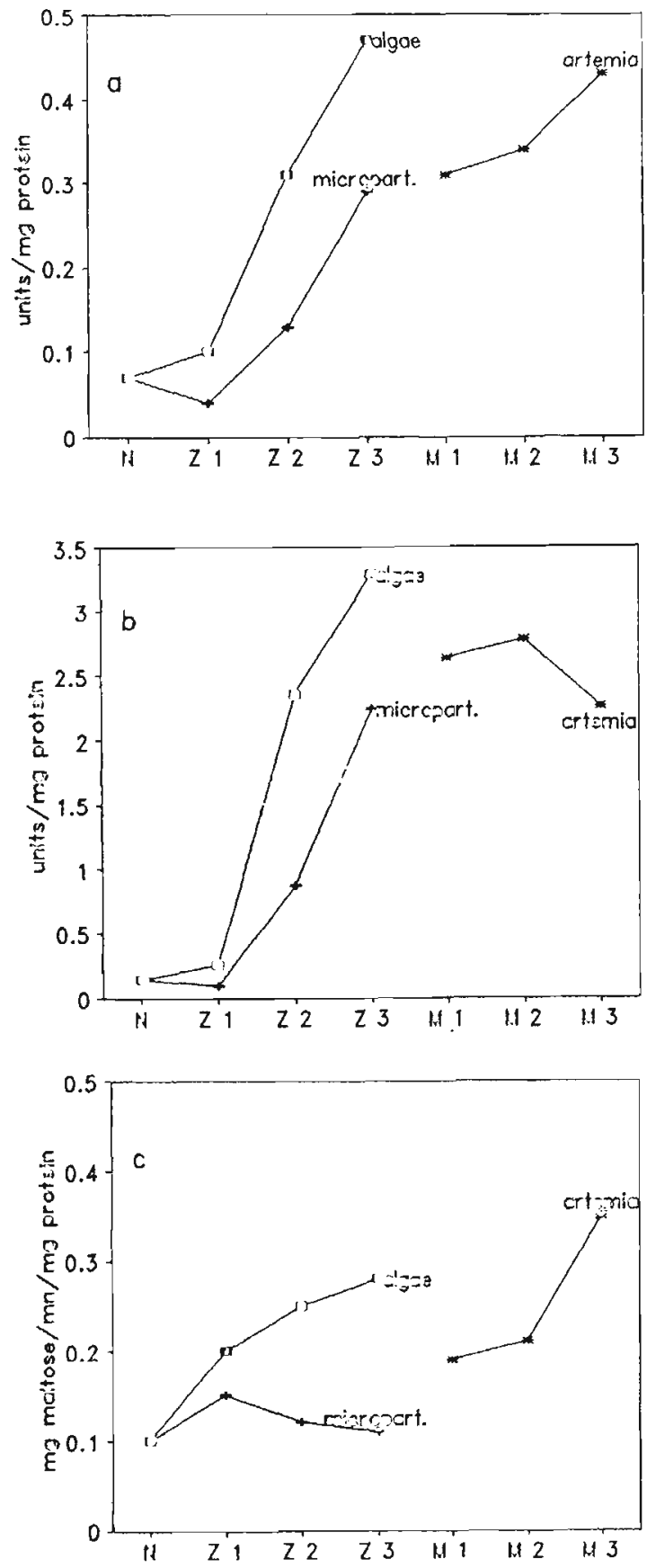

Fizse 2. - Comparison of specific activities of some digestive enzymes in zoe substages fed with algae and microparticles and in mysis substages were fed with Artemia nauplii. Specific trypsin (a), chymotrypsin (b) and amylase (c) activities. Each point represents the mean of two ubservations. of trypsin and chymotrypsin activity corresponded to $1 \mu$ mole of $\mathrm{p}$-Nitroanilide liberated in one minute and amylase activity was defined as $\mathrm{mg}$ of maltose liberated in one minute at $37^{\circ} \mathrm{C}$.

\section{Data and statistics}

Larval growth, trypsin, chymotrypsin and amylase activities were measured in each tank. Data from each tank were pooled between the late zoe 2 and the zoe 3 . Dose-response experiments were computed by simple regression. Comparison experiments were computed with ANOVA.
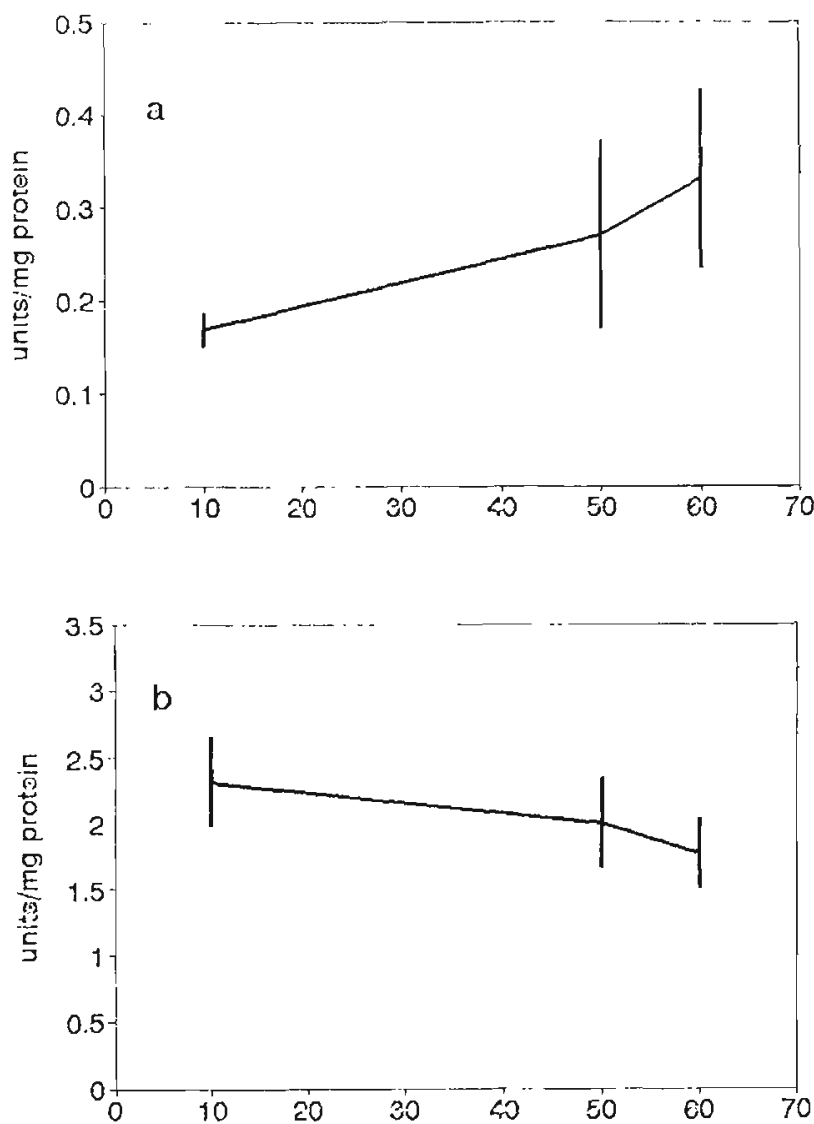

Fizure 3. - Effect of protein level (1,50 and 60\% casein) in diet on specific trypsin (a) and chymotrypsin (b) activitics. Vertical bars represent standard deviation $(n=4)$.

\section{RESULTS}

\section{Effect of live food and artificial diat on} growti and cirestive enzymes

Survival from nauplius to $\mathrm{Z} 3$ of control larvae was 75 and $71 \%$ for experimental larvae, between M1 and M3 survival was $90 \%$. Figure I $a$ shows the increase in length of laboratory-reared $P$. vannamei 
Table 4. - Effect of protein and starch level on larval development. Results are expressed in \% of Z3 at day 8 . Each result is the mean of two observations of each treatment with standard deviation.

\begin{tabular}{lccc}
$\begin{array}{l}\text { Protein level (\% of } \\
\text { casein) }\end{array}$ & $\begin{array}{c}\mathrm{Z3} \\
(\%)\end{array}$ & $\begin{array}{c}\text { Carbohydrate level }(\% \\
\text { of starch) }\end{array}$ & $\begin{array}{c}\mathrm{Z3} \\
(\%)\end{array}$ \\
\hline 10 & $72(2)$ & 1 & $20(12)$ \\
50 & $75(6)$ & 10 & $100(0)$ \\
60 & $99(1)$ & 20 & $100(0)$ \\
\hline
\end{tabular}

larvae. Sizes of larvae were not different for zoe larvae fed algae or microparticles. Soluble protein content in developmental stages of $P$. vannamei increased regularly between $\mathrm{Z1}$ and $\mathrm{M} 3$ substage (fig. $1 b$ ). Zoe larvae fed microparticles contained less soluble protein than larvae fed algae. A same pattern of ontogenetic change in specific enzyme activity was observed with trypsin, chymotrypsin and amylase. Specific trypsin and chymotrypsin activities increased during zoe substage development but less so for larvae fed microparticles (fig. $2 a, b$ ). Amylase activity remained low and did not change during zoe stage when larvae were fed microparticles. At mysis stage, specific enzymatic activities slowed down.

\section{Effect of protein level and carbohydrate level}

Best growth was obtained with a diet containing $60 \%$ casein (table 4), at day $8,100 \%$ of larvae fed with this diet were $\mathrm{Z3}$, whereas only $75 \%$ of larvae were $\mathrm{Z} 3$ with microparticles containing less casein. Specific trypsin activity was positively $(p<1 \%)$ correlated to the casein level in diet (fig. $3 a$ ). Specific chymotrypsin was not correlated to the dietary casein level (fig. $3 b$ ).

At day 8 , all larvae fed microparticles containing $10 \%$ and $20 \%$ starch were $\mathrm{Z} 3$ whereas larvae fed diet containing $1 \%$ starch were only $20 \%$ Z3 (table 4). Starch between 1 and $20 \%$ in microparticles had no influence on specific amylase activity (fig. 4).

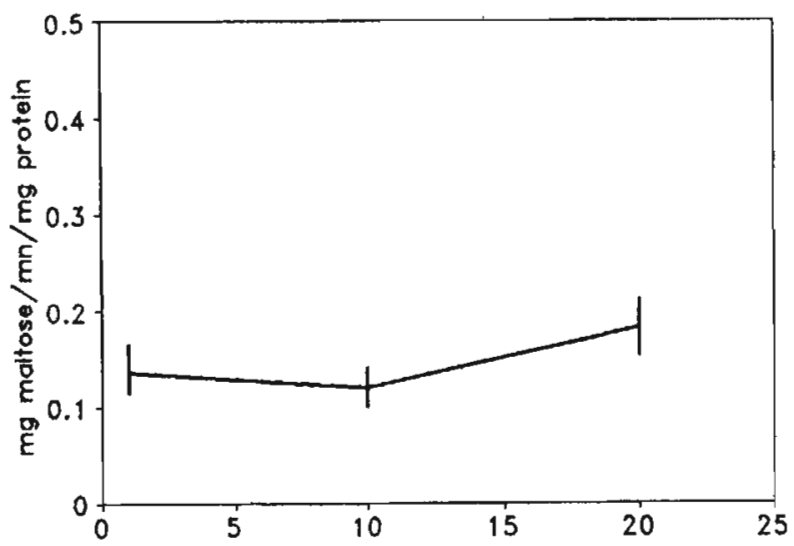

Figure 4. - Effect of starch level (1,10 and $20 \%$ soluble starch) in diet on specific amylase activity. Vertical bars represent standard deviation $(n=4)$.
Table 5. - Effect of protein source and starch quality on larval development. Results are expressed in term of days to teach Z3. Each result is the mean of the two observations of each treatment.

\begin{tabular}{lccc}
\hline Protein source & Z3 & Starch quality & Z3 \\
\hline Casein & 8 & A1 & 8 \\
Gelatin & 8 & A2 & 8 \\
Squid meal & 7 & A3 & 8 \\
Fish protein soluble & 7 & A4 & 8 \\
\hline
\end{tabular}

\section{Influence of protein and carbohydrate quality}

CAL and CPSP stimulated the best growth, at day 7 all zoe fed microparticles containing CAL or CPSP were $\mathrm{Z} 3$ but larvae fed diets containing CAS or GEL were Z3 only at day 8 (table 5). CPSP gave the lowest trypsin activity $(p<5 \%$ ) (fig. $5 a$ ). CAL induced the highest specific chymotrypsin activity $(p<2 \%)$ (fig. $5 b)$.

The starch quality has no effect on larval development (table 5), larvae were $\mathrm{Z3}$ at day 8 . Specific amylase activity was significantly higher $(p<2 \%)$ when larvae were fed microparticles
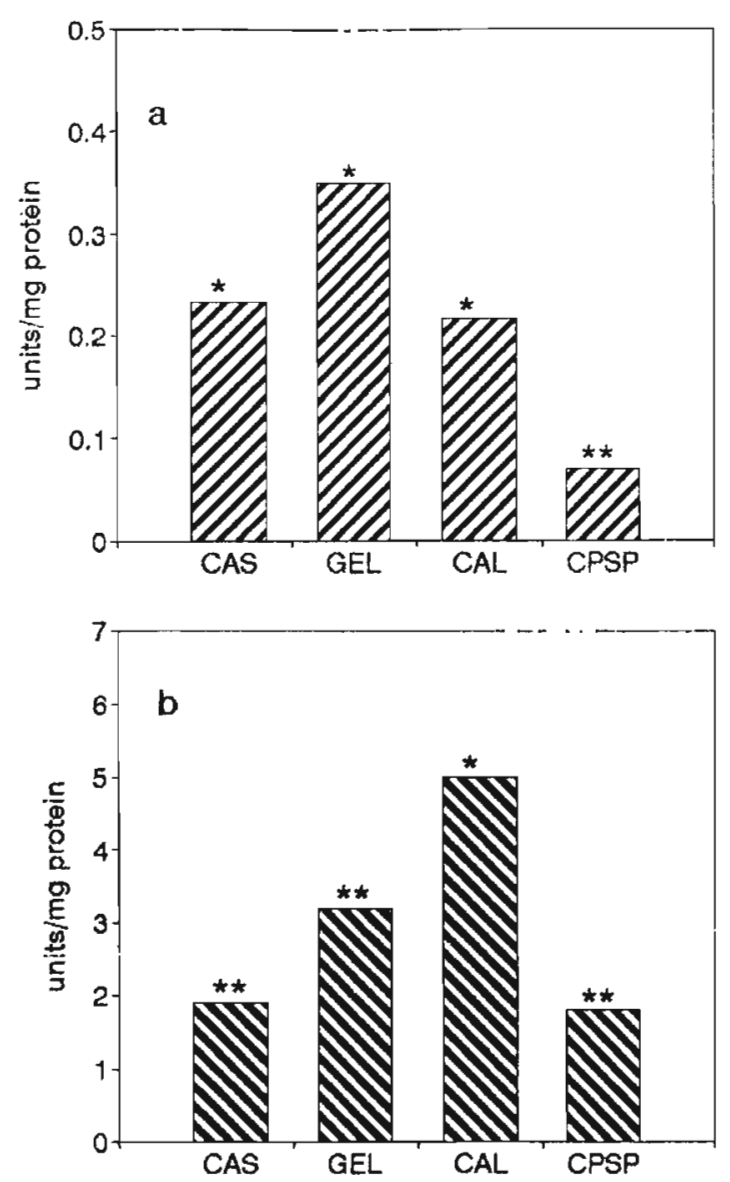

Figure 5. - Effect of protein sources on specific trypsin (a) and chymotrypsin (b) activities. Bars represent mean values $(n=4)$. CAS: casein; GEL: gelatin; CAl: squid meal; CPSP: fish protein soluble concentrate. 


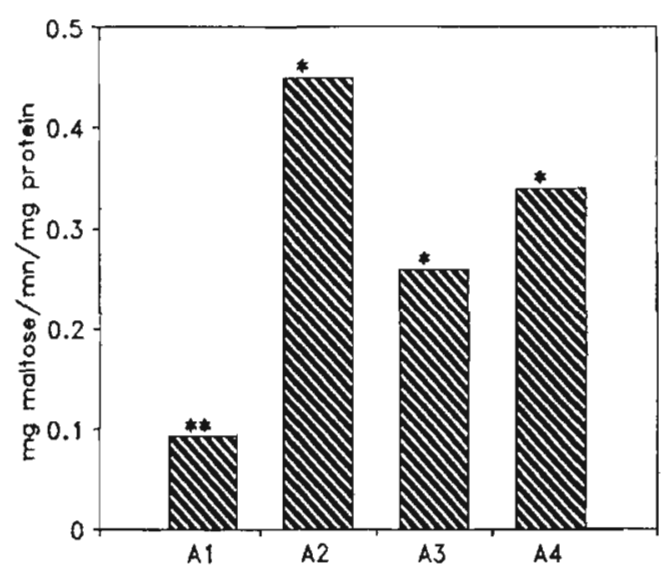

Figure 6. - Effect of starch qualities on specific amylase activity. Bars represent mean values $(n=4)$. A1: soluble starch; A2: standard corn starch; A3: amylopectin corn starch; A4: pregelatinized corn starch.

containing corn starch (A2, A3, A4) compared to soluble starch (A1). No significant differences were observed between different quality of com starches (fig. 6).

\section{DISCUSSION}

Our results show that the increase of the total soluble protein content is correlated to larval growth as described by Laubier-Bonnichon et al. (1977), Lovett and Felder (1990). It corresponds to an increase of the digestive gland volume, described for Penaeus setiferus by Lovett and Felder (1989), and measured for P. monodon larvae by Abubakar and Jones (1991) also found in this study. Moreover, our results show that variations in soluble protein content in $P$. vanname $i$ larvae are also correlated with the food quality. Specific enzymatic activities follow the same pattern as soluble protein content with regard to larval growth and food.

Such factors as moulting, time of day and temperature may influence enzyme activities and at least four feed-related factors can be the source of variations: food type (living or inert), size, density and quality. Opposition between live food (algae) and inert particles may lead to chemically mediated food attraction. Algae $(3-4 \mu \mathrm{m})$ are smaller than microparticles $(<125 \mu \mathrm{m})$ which have a large range of size. Several studies on small crustaceans like copepods show that no species selects food with respect to particle size (Frost, 1977; Poulet, 1978). Food density is a factor regulating ingestion: cell ingestion rate increases until a maximum and a saturation response to cell concentration is observed in $P$. indicus larvae (Emmerson, 1980) and in copepods (Frost, 1972). Food quality is the major determinant of ingestion rate in zooplankton in particular the protein content of phytoplankton (Cowles et al., 1988).

Cellulose used as ballast in our experimental diets do not seems to have any influence on growth and enzyme activities. Akiyama et al. (1989) have shown that dietary fibres, such as cellulose, were poorly digested by $P$. vanname $i$. In these conditions, it cannot influence directly digestive enzyme synthesis as shown by our experiments. The fact that chymotrypsin and amylase did not vary while trypsin varied with protein level suggest also that the cellulose, we have used, has no chromatographic effect on enzymes, by adsorption in the digestive tract.

The results presented indicate that larval growth depends on adjustment to the nutritional needs: the highest larval growth was obtained with diet containing $60 \%$ casein and $10 \%$ starch in artificial diet confirming the results obtained by Teshima and Kanazawa (1984). Trypsin varied with the protein level in microparticles at zoe stage whereas chymotrypsin did not vary in the same conditions. For Palaemon serratus and Homarus gammarus juveniles (Van Wormhoudt et al., 1980; Lucien-Brun et al., 1985), specific trypsin activity is correlated to protein level in the diet up to a maximum, respectively 45 and $37 \%$, and decreases beyond that. In Penaeus setiferus adults, however Lee and Lawrence (1985) have detected a repressive regulatory mechanism of enzyme activity with regard to substrate level in food.

In fact, the choice of ingredients is an important parameter to accelerate penaeid growth (Cuzon and Guillaume, 1984) and also to influence digestive enzymes (Van Wormhoudt et al., 1986). Lee et al. (1984) have shown that the protein source (animal and plant protein) as well as size of shrimps influences the level of protease activities: animal protein induces a high level of enzyme activities in small shrimps but not in larger shrimps. Our conclusions confirm these results: CAL and CPSP accelerated larval growth in comparison to casein and gelatin and it is admitted that squid meal contains a factor promoting shrimp growth (Cruz-Rique, 1987; Revol-Mendoza, 1992). Previous results, obtained in P. japonicus juveniles, show that this growth effect is accompanied by an increase of specific amylase, protease and trypsin activities when squid meal is incorporated at $10 \%$ into the formula in addition to the other protein sources (Van Wormhoudt et al., 1986). Our results confirm that protein quality seems to be one of the factors regulating specifically the enzyme activities in larvae: we report here that with CPSP, the levels of trypsin and chymotrypsin activities are the lowest and may be the consequence of hydrolysate preparation. Chymotrypsin is stimulated significantly when protein source is CAL. However these changes are not correlated with growth at least during the early stages of development.

Concerning carbohydrates, starch level influences growth but not amylase activity; at $1 \%$ starch in food, growth is slowed down. As suggested by Van Wormhoudt et al. (1980), low levels are sufficient and induction has to be determined at these levels. Glucose in larval food (3\%) rapidly assimilated, is probably a factor restricting amylase activity and could explain the absence of response of amylase at the different 
rates of starch. In rat, glucose level in blood is one of the factors determining amylase secretion (Ben Abdeljlil et al., 1963). Other experiments have to be done to determine the role of glucose in haemolymph of inducing amylase secretion in shrimps. Yet, glucose is probably not involved alone in the regulation of amylase activity. The importance of starch origin is also shown because it is a factor of amylase variation in Penaeus vannamei larvae. This may be due, according to Gray (1992), to digestibility of starch depending on its origin and on its structure. Technological treatments (cracking, cooking) enhance starch digestion by converting it from a crystalline to a gel structure.
In conclusion, it appears that during the first stages of larval development an adaptation of trypsin to the casein level in food and of trypsin, chymotrypsin and amylase to the food quality exists as in adults. The increase of trypsin, but not chymotrypsin is correlated to the casein level in the diet and is parallel to the growth. This specific induction may be due to the protein quality and is different according to the protein quality. Squid meal or fish protein soluble concentrate improved larval growth while they have contradictory effects on digestive enzymes. These adaptations however does not seem to have an immediat effect on growth and long term experiments should be done to confirm these results.

\section{Acknowledgements}

This work has been carried out within the "Unité de Recherche Marine" No 14 associating IFREMER with the Collège de France. The authors wish to thank Dr Addison L. Lawrence and Dr R. W. Hardy for critical review of this paper.

\section{REFERENCES}

Abubakar M. A., D. A. Jones, 1992. Functional morphology and ultrastructure of the anterior midgut diverticulae of larvae of Penaeus monodon Fabricius, 1798 (Decapoda, Natantia). Crustaceana, 62, 142-158.

Akiyama D. M., S. R. Coelho, A. L. Lawrence, E. H. Robinson, 1989. Apparent digestibility of feedstuffs by the marine shrimp Penaeus vannamei Boone. Nippon Suisan Gakkaihi, 55, 91-98.

AQUACOP, 1982. Penaeid larval rearing in the Centre Océanologique du Pacifique. In: Handbook of Mariculture. Vol. 1. Crustacean Aquaculture. CRC, Press, Inc. Boca Raton, Florida, USA 1983.

AQUACOP, G. Cuzon, G. Le Moullac, 1990. El uso de dieta microparticuladas en la alimentation larvaria del camaron. In: La Acuacultura del Camaron, Langostino y Cangrejo en el Mundo: Bases y Technologias. Claudio Chavez J. ed., Tokyo University of Fisheries.

Aujero E. J., O. Millamena, E. T. Tech, S. G. Javellana, 1983. Nutritional value of five marine phytoplancton species isolated from Philippines waters as food for the larvae of Penaeus monodon. Contribution 125, Aquac. Dep. SEAFDEC, Iloilo, Philippines.

Ben Abdeljlil A., A. M. Visani, P. Desnuelle, 1963. Adaptation of the exocrine secretion of rat pancreas to the composition of the diet. Biochem. Biophys. Res. Commun., 10, $112-116$.

Bernfeld P., 1954. Sur une méthode de microdosage des amylases. In: Methods in Enzymology. S. P. Colowick, N. O. Kaplan, eds., Academic Press, New York, 149-157.

Cowles T. J., R. J. Olson, S. W. Chisholm, 1988. Food selection by copepods: discrimination on the basis of food quality. Mar. Biol., 100, 41-49.
Cruz-Rique L. E., 1987. Recherche sur la nature et le mode d'action d'un "facteur de croissance" extrait du calmar, dans la nutrition des crevettes pénéides (Crustacea, Decapoda). Thèse dr., Univ. Bretagne Occidentale, Brest, France, 114 p.

Cuzon G., C. Cahu, J. F. Aldrin, J. L. Messager, G. Stéphan, M. Mével, 1980. Starvation effect on metabolism of Penaeus japonicus. Proc. World. Maricul. Soc., 11, 410-423.

Cuzon G., J. Guillaume, 1986. Choix des matières premières et fabrication des aliments destinés aux crevettes d'élevage. In: La Nutrition des Crustacés. Colloque CNERNA, Paris, mai 1986, coord. C. L. Léger, 179-190.

Delmer E. G., C. Largman, J. W. Brodrick, M. C. Geokas, 1979. A sensitive new substrate for chymotrypsin. Anal. Biochem., 99, 316-320.

Emmerson W. D., 1980. Ingestion, growth and development of Penaeus indicus larvae as a function of Thalassiosira weissflogii cell concentration. Mar. Biol., 58, 65-73.

Erlanger B. F., N. Kokowsky, W. Cohen, 1961. The preparation and properties of two chromogenic substrates of trypsin. Arch. Biochem. Biophys., 95, 271-278.

Fang L. S., B. N. Lee, 1992. Ontogenetic change of digestive enzymes in Penaeus monodon. Comp. Biochem. Physiol., 103B, 1033-1037.

Frost B. W., 1972. Effects of size and concentration of food particles on the feeding behaviour of the marine planktonic copepod Calanus pacificus. Limnol. Oceanogr., 17, 805-815.

Frost B. W., 1977. Feeding behavior of Calanus pacificus in mixtures of food particles. Limnol. Oceanogr., 22, 472-491.

Gray G. M., 1992. Starch digestion and absorption in nonruminants. J, Nutr., 122, 172-177. 
Harms J., K. Anger, S. Klaus, B. Seeger, 1991. Nutritional effects on ingestion rate, digestive enzyme activity and biochemical composition of Hyas araneus L. (Decapoda: Majidae) larvae. J. Exp. Mar. Biol. Ecol., 145, 233-265.

Harris R. P., J. F. Samain, J. Moal, V. Martin-Jézéquel, S. A. Poulet, 1986. Effects of algal diet on digestive enzyme activity in Calanus helgolandicus. Mar. Biol, 90, 353-361.

Head E. J. H., R. J. Conover, 1983. Induction of digestive enzymes in Calanus hyperboreus. Mar. Biol. Lett., 4, 219-231.

Hirsche H. J., K. Anger, 1987. Digestive enzyme activities during larval development of Hyas araneus (Decapoda, Majidae). Comp. Biochem. Physiol, 87B, 297-302.

Jones D. A., A. Kanazawa, K. Ono, 1979. Studies on the nutritional requirements of the larval stages of Penaeus japonicus using microparticulate diets. Mar. Biol., 54, 261-267.

Kanazawa A., S. Teshima, S. Tokiwa, 1977. Nutritional requirements of prawn. VII. Effects of dietary lipids on growth. Nippon Suisan Gakkaishi, 43, 849-856.

Koshio S., A. Kanazawa, S. Teshima, 1992. Search for effective protein combination with crab protein for the larval kuruma prawn Penaeus japonicus. Nippon Suisan Gakkaishi, 58, 1083-1089.

Laubier-Bonnichon A., A. Van Wormhoudt, D. Sellos, 1977. Croissance larvaire contrôléc de Penaeus japonicus Bate. Enzymes digestives ct changements de régimes alimentaires. $3^{\text {rd }}$ Meeting of the ICES Working group on Mariculture, Brest, France, May 10-13, 1977, Actes de Colloques du CNEXO, 4, 131-145.

Lee P. G., L. L. Smith, A. L. Lawrence, 1984. Digestive proteases of Penaeus vannamei Boone: relationship between enzyme activity, size and diet. Aquaculture, 42, 225-239.

Lee P. G., A. Lawrence, 1985. Effects of diet and size on growth, feed digestibility and digestive enzyme activities of the marine shrimp, Penaeus setiferus Linnaeus. J. World Maricul. Soc., 16, 275-287.

Lovett D. L., D. L. Felder, 1989. Ontogeny of gut morphology on the white shrimp Penaeus setiferus (Decapoda, Penaeidae). J. Morphol., 201, 253-272.

Lovett D. L., D. L. Felder, 1990. Ontogenic change in enzyme activities of larval and postlarval white shrimp Penaeus setiferus (Crustacea, Decapoda, Penaeidae). Bull. Biol., 178, 146-159.

Lowry O. M., N. J. Rosebrough, A. L. Farr, R. J. Randall, 1951. Protein measurement with the Folin phenol reagent. J. Biol. Chem., 193, 256-275.
Lucien-Brun H., A. Van Wormhoudt, A. Lachaux, H. J. Ceccaldi, 1985. Effets de régimes composés sur la croissance de homards juvéniles, Homarus gammarus L.: estimation biochimique de la composition optimale du régime alimentaire en protéines. Aquaculture, 46, 97-109.

Mendoza-Revol A., 1992. Stimulation de la croissance des crevettes pénéides par un facteur extrait du calmar. Thèse dr., Univ. Bretagne Occidentale, Brest, France, 153 p.

Mock C. R., M. A. Murphy, 1969. The culture of larval penaeid shrimp. Trans. Am. Fish. Soc., 98, 751-754.

Poulet S. A., 1978. Comparison between five coexisting species of marine copepods feeding on naturally occurring particulate matter. Limnol. Oceanogr., 23, 1126-1143.

Rubio Rincon E., 1993. Comparaison biochimiques de trois espèces d'algues monocellulaires issues de cultures en bloom ou en semi-continu. Rapp. DEA, Univ. Bretagne Occidentale, Brest.

Sun Pan B., C. C. Lan, T. Y. Hung, 1991. Changes in composition and proteolytic enzyme activities of Artemia during early development. Comp. Biochem. Physiol, 100A, 725-730.

Samain J. F., A. Hernandorena, J. Moal, J. Y. Daniel, J. R. Le Croz, 1985. Amylase and trypsin activities during Artemia development on artificial axenic media; effect of starvation and specific deletions. J. Exp. Mar. Biol. Ecol., 86, 255-270.

Teshima S., A. Kanazawa, 1983. Effect of several factors on growth and survival of the prawn larvae reared with microparticulate diets. Bull. Jpn. Soc. Sci. Fish., 49, 1893-1896.

Teshima S., A. Kanazawa, H. Sasada, 1983. Nutritional value of dietary cholesterol and other sterols to larval prawn, Penaeus japonicus Bate. Aquaculture, 31, 159-167.

Teshima S., A. Kanazawa, 1984. Effects of protein, lipid and carbohydrate levels in purified diets on growth and survival rates of the prawn larvae. Bull. Jpn. Soc. Sci. Fish., 50, 1709-1715.

Van Wormhoudt A., H. J. Ceccaldi, B. J. Martin, 1980. Adaptation de la teneur en enzymes digestives de l'hépatopancréas de Palaemon serratus (Crustacea, Decapoda), à la composition d'aliments expérimentaux. Aquaculture, 21, 63-78.

Van Wormhoudt A., E. Cruz, J. Guillaume, P. Favrel, 1986. Action de l'inhibiteur trypsique de soja sur la croissance et l'activité des enzymes digestives chez Penaeus japonicus (Crustacea, Decapoda): rôle éventuel des hormones gastro-intestinales. Océanis, 12, 305-319. 